\title{
Online Driver Crisis in Dealing With Customers in Yogyakarta During Covid-19 Pandemic
}

\author{
Kristina Andryani \\ Mercu Buana University Yogyakarta \\ Email: kandryani@mercubuana-yogya.ac.id \\ *corresponding author
}

Keywords:

Online Driver Crisis, Customers, Yogyakarta, Pandemic

\begin{abstract}
The pandemic situation in early 2020 was experienced by almost all regions in the world, including Indonesia. The pandemic has an extensive impact on the life of the country's economy, especially in terms of transportation or narrower transportation service for people, which is an online motorcycle applicationbased service with a smaller scope than other public transportation. The purpose of this paper is to see the crisis that occurs in drivers for services provided amid a pandemic situation like this with various binding rules related to the limitation of human movement from one place to another, which can even lead to crowds. The method used in searching for data was conducting in-depth interviews with several online motorcycle taxi drivers and group discussions to dig deeper into information, and the results obtained from this research were the best services that must be prioritized even though the rules and regulations during the PSBB period bind online motorcycle drivers. Several cases that went viral on social media related to orders that did not match could be addressed from the start by referring to the stages of crisis management, and by looking at the problems that occur, in the future, it is expected that the applicator can manage the problem into a well-patterned system.
\end{abstract}

Copyright (C) 2021 Channel Jurnal Komunikasi. All right reserved.

\section{INTRODUCTION}

Seeing the growing number of the world's population, the greater the need for more food, drink, shelter, and transportation. It can be imagined that the growing population will increase the number of vehicles or transportation routes opened in a particular area. There is no denying that this is also the case in the Special Region of Yogyakarta. The increasing number of vehicles can be proven by the congestion that occurs every hour. Such as in the morning, many people start their work activities and in the afternoon before work hours. Even today, congestion can not be predicted because this can happen anywhere. The Head of Department Transportation of the Special Region of Yogyakarta, Sigit Sapto Raharjo, revealed that growth in the volume of motor vehicles in the DIY region is also inevitable. Every year, the number of new vehicles continues to grow. In Jogja alone, said Sigit, there are new cars around 4\% and new motorcycles around $6 \%$ every year. This number does not include data from four other districts in the Special Region of Yogyakarta (Dishub.jogjaprov.go.id, 2019).

Technological development makes activities online so that transportation emerges in addition to its conventional nature. There is also a modern mode of transportation. One of them is an online rider service that provides convenience in delivering the public to the destination without waiting long, so it is very much felt to facilitate the community or young people living in the millennial community, where everything is online.

The presence of modern transportation with an online system is not only initiated by one type of company. Today, there are about 3 to 5 different types of vendors. Nevertheless, in this case, the focus is the type of online transportation application-based, namely Gojek and Grab, where both vendors currently still have many customers despite the similar competitors popping up. In addition to providing this type of shuttle service, the two vendors also provide other service models such as food delivery, cleaning services, package delivery services to affordable areas, and several other types of services. 
The proliferation of online transportation in our country, Indonesia, is expected to improve economic welfare with the availability of new types of jobs and at least slightly accelerate transportation services for the public with the presence of online motorcycle taxis so that they can unravel congestion that occurs, especially helping the conventional type of transportation mode system. Based on research, which was revealed by Andre Soelistyo as President of the Gojek Group: for Gojek in 2020, exactly a decade of this service was established, now it has more than 38 million monthly active users in Southeast Asia besides Indonesia, including in Vietnam, Singapore, and Thailand. Gojek's business growth is also quite good amid the Covid-19 pandemic, which has a significant impact on the economy, and Gojek has succeeded in scoring an operational profit or positive contribution margin.

Unlike Grab, this application has won the Best Everyday APP award at the 2021 Selular Award (Seluar.id, 2021). This award was achieved based on several categories given by Grab as a super app application provider, meaning all services such as transportation services, document delivery to ordering food, and other services. The health consultation is in this application. For example, during the pandemic that began in March 2020, Grab Health also experienced an increase in requests for health consultations reaching 10,000 per day compared to before the pandemic. Grab services are available in 125 cities throughout Indonesia, Grab, and Gojek have expanded in Southeast Asia, such as Singapore, the Philippines, Malaysia, Vietnam, Myanmar, Cambodia, and the Middle East region.

There is a positive increase in the two applications mentioned above, both in terms of users and other services, making the community's needs more diverse. However, during a pandemic situation, everything must be limited, including in terms of movement or movement of people and goods from one place to another, especially regulations that implemented by the central government which must be forwarded to the regional government so that the policies of each region are not necessarily the same as those in other regions with different conditions for the spread of the virus in each region (Riswanto, Tumuwe, et al., 2018).

There is also a tightening for regions that are felt to have community movements in carrying out work that can trigger the rate at which individuals are exposed to the virus quickly, especially for the Yogyakarta area itself. This city is a city with tourism and cultural potential that is very attractive to tourists both from within its own country and abroad, so that need to be vigilant by making good rules and policies related to the pandemic conditions that have been increasing some time ago so that the community. Significantly the merchant group does not worsen with the conditions and situation of this pandemic.

From here, we can see how the above background can be taken into a problem that can be formulated to be researched or studied together. The crisis faced by online motorcycle taxi drivers is the risk of customer service in the Yogyakarta area during the 2020 pandemic if in carrying out work, there are problems even which can lead to termination of employment with the company.

\section{LITERATURE REVIEW}

\section{A. Crisis Concept}

Talking about a crisis should begin by referring to good communication so that the crisis will not occur or be minimized when the crisis arises. The importance of establishing effective communication can give rise to a sense of understanding and the establishment of a relationship that can achieve common goals. Etymologically, communication comes from Latin, which is cum which means with or together with, and the word units, a number word meaning one. The two words form the noun communion, which means togetherness, unity, combined communions, association, or relationship because communication takes effort and work (Nurjaman \& Umam, 2012). There is effective communication whenever the communicator delivers a message, and the communion receives the message well. Then this goes into the realm of speech or rhetoric that must be done to sustain good communication and become the territory of the concept of public relations because it relates to the public or the wider community.

Pioneering public relations educator Rex Harlow once compiled about 500 definitions. However, the definition can be summarized as follows Good appearance appreciated by society, PR stands for Performance-appearance and Recognitions-recognition, Works well, gets praise, Actions were taken to support a favorable relationship with the general public, Organizational efforts to get cooperation from a group of people (Nurjanah, Ardhianti, 2020).

Some people understand that communication-related to public relations and crisis management is only intended for a company or an organization, but it is not the case over time. As individuals or individuals, we must also have the ability in public relations and also be able to control the problems that lead to the crisis so that the purpose of life can run well if planned and directed (Mahargiono \& Cahyono, 2017).

Relationships with many people or various parties at all times always develop according to the needs. There are many definitions related to this definition of public relations. The first is the definition of J.C., Shield, which defines PR as a continuous process of management's efforts to obtain goodwill subscriptions, employees, and the public generally by conducting analysis and improvements to ourselves, out by making statements. Moreover, another definition of W. Emerson Reck says PR is a continuation of the process of determining wisdom, determining services and attitudes tailored 
to the interests of people or institutions so that the person or institution obtains trust and goodwill from them (Saputra \& Nasrullah, 2011).

Both definitions conclude that in essence. Establishing relationships with many people has the goal that the parties served accommodated interests and objectives with the management or individuals who provide services. Which also increasingly penetrated various sectors by adjusting the development of time. Just as today the world has penetrated the era of computers and has even entered the digital era, all service forms must adjust. Otherwise, it will be considered outdated, and all forms of conventional are slower in development, although all of them have advantages and disadvantages.

\section{B. Crisis Management}

A crisis can be felt when entering the digital age. Almost everyone in the world conducts observations through social media. Such activities can impact the sustainability of a business objective of an institution or company and can even have an impact on one's self-image whenever every complaint and input is not responded to quickly. This is called a crisis that will continue to the risks faced.

Democratization and technological developments make the level of public criticism increase. They increasingly understand their rights and obligations. There is an understanding that the presence of a business organization can not be separated from the obligation of the company to the public, especially the surrounding community. The public assesses every company's operations using a public domain. For example, advertising companies that sell their products use the media as a public domain or resources from the environment. Therefore, there is reciprocity from companies, not just profit (Kriyantono, 2010).

Nova (2009) says that the crisis is a test for our existence, both as companies and as individuals. We never know precisely when the crisis is approaching. We can prepare for crises by understanding the correct principles. The three approaches that can be taken in a crisis are as follows: Avoid crises, Handle crises immediately before the crisis gets worse, Find ways to turn crisis into an opportunity.

A crisis is not a disaster but opportunities or gaps that arise to improve the situation to be more prosperous. Crisis response efforts can be made with the following steps (Morissan, 2010):

1. Forecasting; Crisis management aims to keep risk factors and uncertainty factors to a minimum. Therefore, forecasting needs to be done in pre-crisis situations. Pre-crisis can be done by identifying and analyzing opportunities and threats that occur in the business world. The management can do forecasting by laying the crisis on the crisis barometer map.

2. Crisis prevention; preventive measures should be applied to pre-crisis situations. Nevertheless, if the crisis cannot be prevented, management should strive to prevent the crisis from actually occurring.

3. Intervention crisis; intervention in crisis aimed at ending the crisis. Damage control is carried out at an acute stage. Damage control measures begin with identification, isolation/ exclusion, limiting, suppressing, and ending with recovery.

4. Service Management; Everyone has the potential to experience a crisis in themselves. Everyone is expected to overcome the problems that occur in the sense of being public relations for themselves. Suppose we try to make a good and positive impression of ourselves to others. Then actually, we have performed the public relations function for ourselves. Communication is one of the most important aspects, but it is also complex because communication has a vital role in human life.

In everyday life, everyone receives many messages coming from various sources. Paul F. Lazarsfeld reveals in his book Morissan that: Some messages may attract our attention, but fewer messages can have an effect or impact. Mass communication observers then refer to these kinds of people as 'obstinate audiences.'

Public relations practitioners are one of the parties that participate in competing for the attention of the audience. The first task of the public relations practitioner is to get the attention of the target audience. Secondly, to attract the interest (interest) of the audience to the content of the message, the third builds a desire and the intention of the audience to act following the message conveyed (Morissan, 2010).

According to Wilbur Schramm, communicating to audiences is not as simple as Shannon and Weaver's communication model suggests (Morissan, 2010). Schramm says communicating with the desired target public is, in fact, even more, complicated. According to Schramm, it is humans who make communication complicated. The concept of Schramm communication requires a two-way process in which the sender and recipient of the message are communicated in the context of the frame of reference, their respective relationships, and social situations. Thus, communication is the reciprocal process of exchanging signs to inform, instruct or persuade based on shared meanings and conditions through communicator relationships and social contexts (Soemirat \& Ardianto, 2005). 


\section{METHOD}

This study uses a qualitative descriptive approach by looking specifically at the case of risk management services faced by drivers in providing services to customers. This case study method is applied to emphasize the specifications of the units or cases studied by looking at the unique properties and problems that focus on the research (Pawito, 2008). Case study means case review process as well as results of the assessment process.

This research was conducted in Yogyakarta, specifically choosing two online application-based vendors, Gojek and Grab, as research subjects. Stages and techniques of data collection in this study to collect data and facts needed, then there are several stages and techniques in data collections. Several stages and techniques are described as follows: Observation: observations are made to track systematically and directly the symptoms related to the management of risk management conducted by drivers and related companies. Researchers also provide background on social situations and information on subjects that focus on research to work objectively. In-depth and continuous face-to-face interviews are used to extract information from both Gojek and Grab drivers. This interview allows researchers to obtain detailed reasons from respondents' answers, including the respondent's opinions, motivations, values, or experiences. Documents are required to reveal how the subject defines himself, the environment, and the situation he or she faces at a time. Schatman and Strauss asserted that historical documents are necessary inessential research because most of the situations studied have history and often explain aspects of the situation (Moleong, 2013). This study will refer to the records or results of chats of drivers with customers who are judged to risk drivers' work.

Six respondents were used as resource persons to get information from the six sources, divided into 3 Gojek drivers and $3 \mathrm{Grab}$ drivers. Interviews were carried out one by one to balance the information obtained and not potentially the same. It takes about one month in the interview process with resource persons because not all drivers are willing to be asked for information, and also during the beginning of the pandemic, many drivers decided not to run the application temporarily because they collided with the rules imposed by the applicator. After the data is obtained, the authors begin to group the answers from each resource person to be used as material or further analyzed. Things that are not related to discussion but are contained in interview results were reduced and used as a data bank by the researcher focusing on problem formulation at the beginning.

\section{RESULTS AND DISCUSSION}

\section{A. Issues during a Pandemic that are at risk of a crisis}

The year 2020 is colored by the influx of the Covid-19 outbreak, commonly referred to as coronavirus, which decreases all aspects of lifeline, ranging from economic and health to factors of decreasing the level of welfare of the world community and Indonesian citizens in particular. This pandemic outbreak began to enter Indonesia around March 2020 and made all settings in the government focused on handling this pandemic outbreak, not to be missed in terms of transportation, in this case, is application-based online transportation. The data obtained by the author is the transportation online of 2 applications although currently has started to appear some similar applications but what is the picture, in this case, is the driver of the Gojek and Grab applications. The weakening of almost all sectors in people's lives, especially those in the spotlight, is in the economic sector. As well as drivers when doing application-based work in the early days of the pandemic became a controversy in itself. The situation was due to the ban on transporting people because the public must apply the government's rules, namely social distancing. Which is then emphasized again on physical distancing to lower the rate of spread of viruses from people to people, so many drivers are demonstrating against the ban, which can affect their revenue if there is no inclusion from users, in this case, are passengers who often use the Gojek and Grab apps in traveling, ordering food or delivering goods. Some drivers who were the speakers in this research complained that the pandemic period is a tough time for them because not necessarily in one day they work, get customers, or order food and delivery goods based on the application. People in the early days of the pandemic have the greatest fear of leaving the house and comply with the government's advice to stay \#stayathome and always keep a distance from anyone. However, some people still are not disciplined in implementing health protocols following the government's recommendations. Among others, there is no awareness in terms of the wearing of masks. It can be seen directly and often crowding, thus making the spread of this coronavirus from day to day increasing and making all regulations related to the transferor transmission of people from one place to another considerably tightened and impactful Gojek Grab app services.

\section{B. Crisis Management}

1. Forecasting: Risk management that is commonly applied to an organization or company can also be applied to oneself in anticipation of uncertainty or failure in doing a job. A company can begin with good design and planning since the establishment of an organization or company. This situation is applied to online drivers who always aim to provide the best service for customers or customers. No assessment can harm drivers whenever customers feel dissatisfied or not expected, especially during the pandemic where everyone demands something as desired. However, the situation is often not supportive because the government issues many rules during the pandemic. 
Identifying the crisis is the initial stage that the drivers must do because at this stage, determining the continuity of a job to be a driver can be lasting or not in the sense of getting a warning from the Gojek and Grab apps management of the complaints of customers. The identification stages can start with the driver's response, who executes the order if the customer has confirmed the order through the chat feature. The identification is intended to minimize fictitious orders, and drivers must establish more communication with customers. It can minimize the risk that occurs. Such as by asking if there are additional orders in the form of particular records. Alternatively, if a customer wants to use chili how much, the desired drink customers hot or cold, so that the order is more detailed and does not disappoint customers, especially for customers who enter the go food feature, so that information between drivers and customers can be well established. Although not everything that suits the demands of the customers is fulfilled, drivers are expected to be able to provide the best service, and another example is when the driver gets an order that transports passengers as well as luggage, then the driver must sacrifice by sitting only at the end of the motorcycle seat because all of that to get a good rating.

2. Crisis Prevention: Risks can occur anytime and anywhere. The prevention must be realized correctly for workers and employers, in this case, drivers and applicators, the occurrence of risks on the highway while receiving orders from customers, making it very risky for drivers, in particular, those risks can decrease performance and can even lead to a crisis for all users of online motorcycle applications. Some issues occur which are considered trivial or unreasonable by the driver. For example, using a perfume that is not following customer tastes and giving a 2-star rating to drivers automatically decreases the drivers' performance and the condition of drivers who forget to buy orders outside the application. In addition, some drivers do not comply with customers' requests. For example, stop by from one place to another outside the destination chosen on the initial booking. One (1) star is automatically given to drivers so that they are suspended from the application. Some of these things are very detrimental to the drivers because it is considered incompatible with the run system, so the driver should be able to provide the best service possible to customers. From the description above, it can be seen that the risk can include three things. The first is circumstances that lead to a specific set of results, where the results can be obtained with the possibilities that the decision-maker has known. The second is variations in profits, sales, other financial variables. The third is the possibility of a financial problem that affects the company's operations or financial position, such as economic risks, political uncertainty, and industrial problems (Siegel \&Kim in Irham Fahmi:2).

3. Crisis Intervention: With this intervention, all risks that lead to a crisis can be controlled so that they do not impact damage that leads to recovery of a situation. Drivers must be observant before carrying out orders received because everything carried out contains risks that lead to a crisis. Even though it looks simple, transporting people, packages, food from one place to another without following customer requests will lead to a low rating on the customer apps when the order is completed. Identifying risks at this early stage is expected to see the potential that will develop in the future and reduce the loss factors experienced by drivers, which will then become forms of risk that can be predicted. Similar to a crisis, if complaints from customers are not responded to and managed well by the owner of the company (drivers and applicators), it will potentially become a crisis.

\section{Online Motorcycle Driver Risk Management}

The reputation crisis of the drivers is very much at stake in carrying out orders from customers, with the many characters of the customers faced makes the drivers have to work even more, as expressed by Mr. Mukti when receiving food purchase orders in restaurant A. However, customers ask for additional purchases at different restaurants, if it does not materialize, the driver will get a rating, and comments are not good. The assessment of the risks themselves can be seen both objectively and subjectively, which often occurs as a risk with a subjective category, where a person's psychological condition or mood will determine the final result of the drivers' work. In this case, the company must be involved in issues that cause risks for drivers so that drivers have administrative and legal protection in case of unwanted things.

The crisis in online drivers in the pandemic period is felt very heavy, although in the early days of the presence of online-based applications has also caused controversy between online drivers and base drivers, slowly online-based transportation is acceptable to almost all circles of society, both big cities and local communities. However, some transportations are still conventional, for example, base drivers and rickshaws.

The policy during the pandemic related to Large-Scale Social Restrictions caused the number of orders to be reduced so drastically that the applicators reduced the awarding of bonuses to drivers, this is because the applicator was also affected by government regulations on the existence of people transport services in the early days of the pandemic. Another policy is that in the absence of face-to-face lectures for students, it also dramatically affects the income for drivers, considering Yogyakarta is a student city and the most income earned from drivers is from millennial users of online-based applications, so automatically this has caused a crisis for drivers, especially in terms of the economy. With policies that can affect drivers' performance, the applicator also contributes by adding features for customers with notifications to keep distance between drivers and customers. In addition to recommending new procedures in transacting using electronic 
money to minimize direct contact between drivers and customers, the concern of the company or other applicators is to support the transmission of covid 19 by the provision of post for drivers, body temperature checks, and also spraying vehicles periodically on the driver's vehicle and also always recommend to keep using masks and hand sanitizer.

\section{Resolution of The Risks Faced}

In a crisis that occurs in the form of risks for drivers, some things can be used to minimize the occurrence of even more significant risks. Including means of communication from qualified providers. So that there is no disruption in communication between drivers and customers due to network problems. The use of motorcycles or vehicles that are maintained and roadworthy following the standards determined by the applicator. Because it is often seen that motorcycles that should be used personally (sport with a higher rear seat) are used to serve customers, and this is very uncomfortable for some customers who have difficulty sitting in a higher position on the back, especially if they get a middle-aged customer who can accommodate the needs of customers with their luggage. Personality is also significant, especially neatness in dressing using the attributes of online motorcycle taxis, greetings, or establishing good communication during the trip, which gets the immediate attention of customers.

\section{CONCLUSION}

The increasing number of Covid-19 transmissions in the pandemic period until November 2020 forced all industry sectors to design various strategies for achieving the desired goals so that the risks or impacts faced do not worsen. As well as those faced by drivers online transportation, the best service should be the primary goal given to customers, so that the application-based assessment is also good results and can improve the performance of drivers online transportation, of course, various rules can not separate this and types of services that the applicator has well systematized. However, more services from the humanist side can make customers or customers provide other value. Drivers should also be more vigilant in the middle of the pandemic by prioritizing their health or not potentially transmitting the virus to customers and can be more observant in receiving orders, especially those that have the potential to harm drivers or decrease performance.

It started from a risk that then ended in a crisis, bringing its own experience for drivers. Because each driver can experience different risks and crises, there needs to be service management that is applied according to the performance conditions of each driver. Concerning three things in the stages of crisis management are forecasting, prevention and intervention so that every order that is executed can result in a good assessment by the customer and vice versa, the customer gets the best service from the drivers. Several cases that went viral on social media related to orders that did not match could be addressed from the start by referring to the stages of crisis management. By looking at the problems that occur in the future, it is expected that the applicator can manage the problem into a well-patterned system-reducing the risk both from the driver side and customers side. In the future, there will be no more unpleasant things related to customer ratings by giving 2 or 1 star, which will lead to suspension or temporary termination by the applicator to the driver.

\section{REFERENCES}

[1] Dishub.jogjaprov.go.id. (2019). Jumlah Kendaraan di Jogja Terus Bertambah, Rekayasa Lalu Lintas Jadi Solusi. https:/dishub.jogjaprov.go.id/berita/jumlah-kendaraan-di-jogja-terus-bertambah-rekayasa-lalu-lintas-jadi-solusi,

[2] Fahmi, Irham. (2018). Manajemen Risiko: Teori Kasus dan Solusi. Alfabeta.

[3] Hanafi, Mamdun M. (2014). Manajemen Resiko. UPP STIM YKPN.

[4] Kriyantono. (2010). Teknis Praktis Riset Komunikasi, Disertai Contoh Praktis Riset Media, Public Relations, Advertising, Komunikasi Organisasi, Komunikasi Pemasaran. Kencana Prenada Media Group

[5] Kumparan.com. (2020) 10 Tahun Gojek: 38 Juta Pengguna Aktif Bulanan Hingga Cetak Laba. https://kumparan. com/kumparantech/10-tahun-gojek-38-juta-pengguna-aktif-bulanan-hingga-cetak-laba-1uZiKid82Mo

[6] Moleong, L. (2013). Metodologi Penelitian Kualitatif, Paradigma Baru Ilmu Komunikasi dan Ilmu Sosial Lainnya. PT. Remaja Rosdakarya.

[7] Morissan. (2010). Manajemen Public Relations: Strategi Menjadi Humas Profesional. Kencana Prenada Media Group.

[8] Nova, Firsan. (2009) Crisis Public Relations-Bagaimana PR Menangani Krisis Perusahaan. Grasindo.

[9] Nurjanah, Ardhianti. (2020). Manajemen Isu Dan Krisis. Litera.

[10] Nurjaman, Kadar., \& Umam, Khaerul. (2012). Komunikasi dan Public Relations. CV. Pustaka Setia.

[11] Pawito. (2008). Penelitian Komunikasi Kualitatif. LKiS.

[12] Soemirat, Soleh, \& Ardianto, Elvinaro. (2005). Dasar-dasar Public Relations. PT. Remaja Rosdakarya. 
[13] Saputra, Wahidin., \& Nasrullah, Rulli. (2011). Public Relations 2.0; Teori dan Praktek Public Relations di era Cyber. Gramata Publishing.

[14] Riswanto, Tumuwe et. al. (2018). Pengguna Ojek Online Di Kalangan Mahasiswa Universitas Sam Ratulangi Manado. HOLISTIK, Journal Of Social and Culture. XI No. 21A. https://ejournal.unsrat.ac.id/index.php/holistik/ article/view/20562

[15] Mahargiono, Pontjo Bambang., \& Cahyono, Krido Eko. (2017). Kontroversi Transportasi Online Sebagai Dasar Pembenahan Fasilitas Layanan Penumpang Bagi Pelaku Bisnis Transportasi Di Surabaya. [Conference Presentation]. Seminar Nasional Multi Disiplin Ilmu SENDI_U. https://www.unisbank.ac.id/ojs/index.php/sendi_u/ article/view/5033

[16] Seluar.id. (2021). Grab Renggut Penghargaan Best Everyday App di Ajang Selular Award 2021. https://selular. $\mathrm{id} / 2021 / 07 /$ grab-renggut-penghargaan-best-everyday-app-di-ajang-selular-award-2021 
